\title{
Erdosteine Versus N-acetyl Cysteine as a Potential Therapy for Hepatorenal Syndrome
}

\author{
ASEM A. ELFERT, M.D.*; KAMAL M. OKASHA, M.D.**; REHAM A. EL-KHOULY, M.D.* and \\ SHAIMAA E. AHMED, M.Sc.** \\ The Departments of Tropical Medicine \& Infectious Diseases* and Internal Medicine**, Faculty of Medicine, Tanta University
}

\begin{abstract}
Background: Hepatorenal Syndrome (HRS) is a unique form of acute kidney injury seen in patients with acute liver failure or chronic liver disease in absence of any other identifiable cause of renal failure. Hepatorenal syndrome is associated with significant morbidity and mortality.

Aim of Study: The aim of this study was to assess the safety and efficacy of Erdosteine versus N-acetyl cysteine with octreotide and albumin in the treatment of hepatorenal syndrome in cirrhotic patients.

Patients and Methods: The study enrolled 60 liver cirrhosis patients diagnosed to have hepatorenal syndrome who were randomized to receive Erdosteine $300 \mathrm{mg}$ or $\mathrm{N}$-acety-lcysteine $600 \mathrm{mg}$ three times daily with octreotide $(100 \mu \mathrm{gsc}$ three times a day) midodrine ( $12.5 \mathrm{mg}$ orally three times a day) and albumin $(1 \mathrm{~g} / \mathrm{kg}$ body weight up to a maximum of $100 \mathrm{~g})$ or receive octreotide, midodrine and albumin as a control for two weeks. Renal function was assessed before and after treatment. Side effects and improvement of liver function were recorded.
\end{abstract}

Results: In NAC group; creatinine level was significantly lower after the second week of therapy than baseline level ( $p=0.006)$, also there was significantly higher GFR after the first and the second weeks of therapy than baseline level ( $p=$ $0.038,0.001$ respectively) and significant higher GFR after the second week than after the first week of therapy ( $p=$ 0.015). Meanwhile, no significant difference of creatinine or GFR was detected in Erdosteine group or when the three groups were compared.

In NAC group, Child-Pugh score significantly improved compared to control group after 2 weeks of therapy ( $p=0.004)$. In the first and second weeks of therapy, the grade of encephalopathy was significantly lower in Erdosteine group ( $p=0.032$, $0.040)$ and in NAC group ( $p=0.009,0.004)$ compared to control group.

The side effects were few with no significant difference between their occurrences in the three groups.

Correspondence to: Dr. Shaimaa Ezaat Ahmed, E-Mail: Dr.shaimaa.ezzat7@.gmail.com
Conclusion: This study was a pilot study that investigated the effects of Erdosteine versus NAC on human patients with HRS. No significant difference of creatinine or GFR was detected when Erdosteine, NAC and control groups were compared. Improvement of Child-Pugh score in NAC group and hepatic encephalopathy in Erdosteine group were secondary outcomes of our study.

As these drugs had a high safety profile, we recommend further studies using higher doses of the drugs for longer periods and enrollment of larger number of patients to optimize treatment of HRS.

Key Words: Erdosteine - N-Acetylcysteine-Cirrhosis -
Hepatorenal.

\section{Introduction}

HEPATORENAL Syndrome (HRS) is a unique form of renal impairment seen in patients with acute liver failure or chronic liver disease in absence of any other identifiable cause of renal failure. Liver transplantation forms the cornerstone for its management [1]. Several meta-analyses that evaluated vasoconstrictor therapies for HRS did not show any significant reduction in mortality without liver transplantation [2-8].

NAC is used as an antidote for acetaminophen overdose, it is also used to treat Non-Acetaminophen-Induced Acute Liver Failure (NAIALF) and severe alcoholic hepatitis. When used to treat severe alcoholic hepatitis, i.v. acetylcysteine serves as an antioxidant and glutathione source. Improvement in patients with hepatorenal syndrome was also noted [9].

Erdosteine belongs to the class of mucolytics which is used for the treatment of wet cough and Chronic Obstructive Pulmonary Disease (COPD) [10]. Many studies showed the beneficial effect of Erdosteine in: Cisplatin-induced hepatic oxidant injury, [11] liver damage induced by acetaminophen 
intoxication, [12] radiocontrast-induced hepatotoxicity, [13] renal ischemic reperfusion injury [14]

The aim of this study was to assess the safety and efficacy of Erdosteine versus $\mathrm{N}$-acetyl cysteine with octreotide, midodrine and albumin in the treatment of hepatorenal syndrome in cirrhotic patients.

\section{Patients and Methods}

\section{Study design and patients:}

This was a randomized, controlled, pilot study conducted in Egypt. A total of 70 cirrhotic patients with hepatorenal syndrome were screened for participation in this study.

The patients had been admitted at Tropical Medicine and Infectious diseases and in Internal Medicine Departments, in Tanta University Hospital from February 2017 till February 2018. Of these, 60 patients with post-hepatitis $\mathrm{C}$ liver cirrhosis with hepatorenal syndrome were enrolled and randomly assigned to receive Erdosteine with octreotide and albumin or N Acetyl cysteine with octreotide and albumin or octreotide and albumin as a control group. The rationale for utilizing Erdosteine and N Acetyl cysteine was that they are safe and inexpensive drugs commonly prescribed as mucolytics in treatment of wet cough. We believed it was unethical to perform a placebobased trial in this category of patients.

The included patients were randomized using a computerized random number generator to select randomly permuted blocks with a block size of four and an equal allocation ratio. Sequentially numbered, opaque, sealed envelopes were used to ensure concealment. An independent observer assigned participants to a computer-generated randomization sequence.

Patients were randomized into 3 equal groups; the first group included 20 patients who were treated with Erdosteine 300mg P.O. three times daily for two weeks in addition to octreotide $(100 \mu$ gsc three times a day) midodrine $(12.5 \mathrm{mg}$ orally three times a day) and albumin $(1 \mathrm{~g} / \mathrm{kg}$ body weight up to a maximum of $100 \mathrm{~g}$ ), the second group included 20 patients who were treated with NAC $600 \mathrm{mg}$ P.O. three times daily for two weeks in addition to octreotide, midodrine and albumin (same doses as in Erdosteine group), and the third group included 20 patients who were treated with octreotide, midodrine and albumin (same doses as in Erdosteine group) for 2 weeks (control group).
Inclusion criteria included patients with posthepatitis C liver cirrhosis and hepatorenal syndrome. Liver cirrhosis was diagnosed on the basis of clinical and laboratory findings as well as abdomino-pelvic ultrasound, evaluation of the severity of liver cirrhosis was obtained in each cirrhotic patient with modified Child-Pugh score [15]. Hepatorenal syndrome was diagnosed according to the International Ascites Club criteria: Cirrhotic patients with serum creatinine $>1.5 \mathrm{mg} / \mathrm{dL}$ without improvement following diuretic withdrawal and plasma volume expansion with intravenous albumin and in the absence of (A) Shock, (B) Renal or gastrointestinal fluid loss, (C) Recent management with nephrotoxic drug, (D) Recent ongoing bacterial infection, (E) Proteinuria > $500 \mathrm{mg} / \mathrm{dL}$, and $(\mathrm{F})$ Ultra sonographic evidences of parenchymal renal disease or urinary tract obstruction [16]

Patients with HCC or liver metastasis, hepatic encephalopathy grade IV and patients with evidence of peptic ulcer disease were excluded from the study.

Institutional ethical committee approval was obtained before the start of the study and informed consent was signed by every patient before enrolment in the study. The study was approved in January 2017 by the Ethics Committee of the Faculty of Medicine, Tanta University (code approval number: $31305 / 01 / 17)$. The study protocol conforms to the ethical guidelines of the 1975 Declaration of Helsinki as reflected in prior approval by the institution's Human Research Committee. All authors had access to the study data, and reviewed and approved the final manuscript.

\section{Assessments:}

Baseline evaluation included clinical examination, abdomino-pelvic ultrasound, and laboratory testing (bilirubin, prothrombin time, albumin, creatinine, Glomerular Filtration Rate (GFR)).

All patients were followed by clinical examination, abdomino-pelvic ultrasound, and laboratory testing after the first and the second weeks of therapy to assess improvement of renal function and Re-evaluate Child-Pugh score.

\section{Outcomes:}

The primary outcome of the trial was the improvement of renal function in the Erdosteine and NAC groups at the end of first and second weeks of therapy. Secondary outcomes were the occurrence of significant adverse events of Erdosteine and NAC and the improvement of liver biochemical tests and modified Child-Pugh score. 


\section{Statistical analysis:}

Statistical presentation and analysis of the present study was conducted, using the mean, standard deviation and chi-square test, standard student " $t$-test", analysis of variance [ANOVA] tests (f): According to the computer program SPSS for Windows. ANOVA test was used for comparison among different times in the same group in quantitative data. Chi-square test was used for comparison between two groups as regards qualitative data. Standard student " $t$-test" was used to test of significance of the difference between two means. Values of $p$ less than 0.05 (two-tailed) were considered statistically significant.

All statistical calculations were performed using the computer program SPSS (Statistical Package for the Social Science; SPSS, Chicago, Illinois, USA) Version 22 for Microsoft Windows.

\section{Results}

In total, 70 patients were screened for study participation out of whom 10 were excluded from the study; of these, 7 failed to fulfill the inclusion criteria, and three declined to participate. Thus, 60 patients were randomized to receive Erdosteine $300 \mathrm{mg}$ P.O. three times daily for two weeks in addition to octreotide and albumin, the second group included 20 patients who were treated with NAC $600 \mathrm{mg}$ P.O. three times daily for two weeks in addition to octreotide and albumin, and the third group included 20 patients who were treated with octreotide and albumin for 2 weeks (control group). The baseline characteristics of patients of the studied groups are summarized in (Table 1).

In our study, there was statistically non-significant difference between all studied groups as regards age, sex, diabetes mellitus, hypertension, and baseline grade of encephalopathy and amount of ascites (Table 1).

There was statistically non-significant difference between all studied groups as regards baseline bilirubin, albumin levels and INR, creatinine, GFR, modified Child-Pugh score. In NAC group, creatinine level was significantly lower after the second week of NAC therapy than baseline level $(p=0.006)$. Also there was significantly higher GFR after the first and second weeks of NAC therapy than baseline level ( $p=0.038,0.001$ respectively) and significant higher GFR after second week than first week $(p=0.015)$ (Table 2).

INR was significantly lower after the second week of NAC therapy than baseline $(p=0.01)$. There was non-significant difference between baseline, after the first week and after the second week of NAC therapy as regards bilirubin and albumin (Table 2).

Of the twenty patients who received NAC therapy, seven patients who had marked ascites improved to moderate ascites and one patient with moderate ascites improved to mild ascites and also three patients who had grade one encephalopathy became grade zero (Table 3 ).

In Erdosteine group, there was non-significant difference between baseline, after first week and after second week of Erdosteine therapy as regards clinical and laboratory parameters of patients. After the first and second week of NAC and Erdosteine therapies creatinine and GFR showed non-significant difference when compared to control group. There was statistically non-significant difference between all studied groups as regards bilirubin and albumin levels after the first and second weeks of therapy. As regards INR, non-significant difference was detected between all studied groups after the first week. After the second week, INR was significantly lower in NAC group than control group $(p=0.007)$ (Table 4).

There was significant difference between all studied groups as regards the grade of hepatic encephalopathy after the first and second week of therapy ( $p=0.006,0.005$ respectively). After the first week the grade of encephalopathy was significantly lower in Erdosteine group $(p=0.032)$ and in NAC group $(p=0.009)$ than control group. Also after the second week the grade of encephalopathy was significantly lower in Erdosteine group ( $p=$ $0.040)$ and in NAC group ( $p=0.004)$ than control group (Table 5).

No significant difference was detected between all studied groups as regards the amount of ascites after the first or the second week of therapy.

As regards Child-Pugh score, non-significant difference was detected between all studied groups after the first week. In the second week, ChildPugh score was significantly lower in NAC group than control group $(p=0.004)$ (Table 6).

The regimen was well-tolerated by all the patients enrolled in the study. No serious adverse events were detected during NAC and Erdosteine therapy. In NAC group 1 patient complained from gastric distress, 1 patient in Erdosteine group complained from nausea. 
Table (1): Baseline demographic and clinical data of all studied groups.

\begin{tabular}{llllll}
\hline & \multicolumn{2}{l}{ Erdosteine NAC } & Control & F/ $\chi^{2}$ & $p$-value \\
\hline Age: & & & & & \\
- Range & $50-85$ & $52-70$ & $47-78$ & $\mathrm{~F}:$ & 0.900 \\
- Mean \pm S.D & $61.05 \pm 7.92$ & $60.40 \pm 4.25$ & $61.40 \pm 8.06$ & 0.106 & \\
Sex: & & & & & \\
- Male: & & & & & \\
- N & 12 & 11 & 13 & $\chi^{2}:$ & 0.812 \\
- \% & $60.0 \%$ & $55.0 \%$ & $65.0 \%$ & 0.417 & \\
- Female: & & & & & \\
- N & 8 & 9 & 7 & & \\
- \% & $40.0 \%$ & $45.0 \%$ & $35.0 \%$ & & \\
Diabetes & & & & & \\
mellitus: & & & & & \\
- Yes: & & & & & \\
- N & 5 & 2 & 5 & $\chi^{2}:$ & 0.392 \\
- \% & $25.0 \%$ & $10.0 \%$ & $25.0 \%$ & 1.875 & \\
- No: & & & & & \\
- N & 15 & 18 & 15 & & \\
- \% & $75.0 \%$ & $90.0 \%$ & $75.0 \%$ & &
\end{tabular}

Hypertension:

-Yes:

$\begin{array}{lllll}-\mathrm{N} & 0 & 0 & 1 & \chi^{2}: \\ -\% & .0 \% & .0 \% & 5.0 \% & 2.034\end{array}$

-No:

$\begin{array}{llll}-\mathrm{N} & 20 & 20 & 19\end{array}$

$\begin{array}{llll}-\% & 100.0 \% & 100.0 \% & 95.0 \%\end{array}$

Ascites:

- Mild:

- N $\quad 2$

$-\%$

- Moderate:

$\begin{array}{llll}-\mathrm{N} & 8 & 11 & 8\end{array}$

$\begin{array}{lll}-\% & 40.0 \% \quad 55.0 \% \quad 40.0 \%\end{array}$

- Marked:

$\begin{array}{llll}-\mathrm{N} & 10 & 7 & 8\end{array}$

$\begin{array}{llll}-\% & 50.0 \% & 35.0 \% & 40.0 \%\end{array}$

Encephalopa-

thy:

- No:

$-\%$

18

$95.0 \%$

17

$85.0 \%$

11

$55.0 \%$

$\chi^{2}: \quad 0.057$

- Grade 1:

$\begin{array}{llll}-\mathrm{N} & 1 & 3 & 3\end{array}$

$\begin{array}{llll}-\% & 5.0 \% & 15.0 \% & 15.0 \%\end{array}$

- Grade 2:

$\begin{array}{llll}-\mathrm{N} & 1 & 0 & 4\end{array}$

$\begin{array}{llll}-\% & 5.0 \% & 0 \% & 20.0 \%\end{array}$

- Grade 3:

$\begin{array}{llll}-\mathrm{N} & 0 & 0 & 2 \\ -\% & 0 \% & 0 \% & 10.0 \%\end{array}$

$\chi^{2}:$ Chi-squared test.

$\mathrm{F}^{*}$ : One way ANOVA.
Table (2): Effect of NAC on clinical and laboratory parameters of patients.

\begin{tabular}{lllll}
\hline & Range & Mean \pm S.D & F-test & $p$-value \\
Parameter & & & & \\
\hline $\begin{array}{l}\text { Bilirubin: } \\
\text { Baseline } \\
\text { 1st wk }\end{array}$ & $0.6-28.3$ & $4.69 \pm 6.44$ & 0.091 & 0.913 \\
2nd wk & $0.2-27.3$ & $4.08 \pm 6.01$ & & \\
Albumin: & $0.2-27.3$ & $3.90 \pm 5.97$ & & \\
Baseline & & & & \\
1stwk & $1.8-3.3$ & $2.40 \pm 0.42$ & 0.617 & 0.543 \\
2ndwk & $1.5-3.5$ & $2.50 \pm 0.59$ & & \\
INR: & $1.5-4.1$ & $2.61 \pm 0.70$ & & \\
Baseline & & & & \\
1st wk & $1.07-2.58$ & $1.74 \pm 0.46$ & 3.519 & $0.036^{*}$ \\
2nd wk & $1.05-2.3$ & $1.56 \pm 0.42$ & & \\
& $1.01-2$ & $1.40 \pm 0.33$ & &
\end{tabular}

Baseline \& 1st wk $(p 1=0.174)$

baseline \& 2 nd wk $(p 2=0.010)$

1 st \& 2nd wk $\quad C p 3=0.207)$

Creatinine:

$\begin{array}{lllll}\text { Baseline } & 1.7-3.8 & 2.26 \pm 0.69 & 4.157 & 0.021 \text { * } \\ \text { 1st wk } & 1.17-3.4 & 1.87 \pm 0.57 & & \end{array}$

lst wk

$1-5.19 \quad 1.60 \pm 0.90$

Baseline \& 1st wk $(p 1=0.094)$

Baseline \& 2nd wk $\left(p 2=0.006^{*}\right)$

1 st \& 2nd wk $\quad p 3=0.249)$

GFR:

$\begin{array}{lllll}\text { Baseline } & 14-52 & 33.10 \pm 11.21 & 10.659 & 0.001 * \\ \text { 1stwk } & 21-80 & 43.25 \pm 15.04 & & \\ \text { 2ndwk } & 13-89 & 55.42 \pm 18.38 & & \end{array}$

Baseline \& 1st wk $(p 1=0.038)$

Baseline \& 2nd wk $(p 2=0.001)$

1 st \& 2nd wk $\quad(p 3=0.015)$

Child-Pugh score:

$\begin{array}{lllll}\text { Baseline } & 7-12 & 10.00 \pm 1.52 & 1.923 & 0.156 \\ \text { 1st wk } & 7-12 & 9.35 \pm 1.46 & & \\ \text { 2nd wk } & 7-12 & 9.15 \pm 1.31 & & \end{array}$

F*: One way ANOVA. *: Denotes statistically significant $p<0.05$.

Table (3): Effect of NAC on the grade of encephalopathy \& the amount of ascites of patients.

\begin{tabular}{|c|c|c|c|c|c|}
\hline Parameter & Baseline & $1^{\text {st }} \mathrm{wk}$ & 2 nd wk & $x^{2}$ & $p$-value \\
\hline $\begin{array}{l}\text { Encephalo } \\
\text { - No: } \\
\mathrm{N} \\
\%\end{array}$ & 17 & 20 & 20 & & \\
\hline $\begin{array}{c}\text { - Grade 1: } \\
\mathrm{N} \\
\%\end{array}$ & $\begin{array}{l}85.0 \% \\
3\end{array}$ & $\begin{array}{l}100.0 \% \\
0\end{array}$ & $\begin{array}{l}100.0 \% \\
0\end{array}$ & 6.316 & $0.043 *$ \\
\hline $\begin{array}{l}\text { - Grade 2: } \\
\mathrm{N} \\
\%\end{array}$ & $\begin{array}{l}15.0 \% \\
0\end{array}$ & $\begin{array}{l}0 \% \\
0\end{array}$ & $\begin{array}{l}0 \% \\
0\end{array}$ & & \\
\hline $\begin{array}{l}\text { - Grade 3: } \\
\mathrm{N} \\
\%\end{array}$ & $\begin{array}{l}0 \% \\
0\end{array}$ & $\begin{array}{l}0 \% \\
0\end{array}$ & $\begin{array}{l}0 \% \\
0\end{array}$ & & \\
\hline $\begin{array}{l}\text { Ascites: } \\
\text { Mild: } \\
\mathrm{N} \\
\%\end{array}$ & $\begin{array}{l}0 \% \\
10.0 \%\end{array}$ & $\begin{array}{l}0 \% \\
10.0 \%\end{array}$ & $\begin{array}{l}0 \% \\
15.0 \%\end{array}$ & & \\
\hline $\begin{array}{c}- \text { Moderate. } \\
N \\
\% \\
\%\end{array}$ & $\begin{array}{l}11 \\
55.0 \%\end{array}$ & $\begin{array}{l}18 \\
90.0 \%\end{array}$ & $\begin{array}{l}17 \\
85.0 \%\end{array}$ & 16.155 & $0.003 *$ \\
\hline - Marked: & $\begin{array}{l}7 \\
35.0 \%\end{array}$ & $\begin{array}{l}0 \\
0 \%\end{array}$ & $\begin{array}{l}0 \\
0 \%\end{array}$ & & \\
\hline
\end{tabular}


Table (4): Effect of therapy on liver biochemical tests between studied groups.

\begin{tabular}{|c|c|c|c|c|c|}
\hline Parameter & Group & Range & Mean \pm S.D & F-test & $p$-value \\
\hline $\begin{array}{l}\text { - Bilirubin } \\
\text { 1st wk }\end{array}$ & $\begin{array}{l}\text { Erdosteine } \\
\text { NAC } \\
\text { Control }\end{array}$ & $\begin{array}{l}0.2-5.7 \\
0.2-27.3 \\
0.7-26.5\end{array}$ & $\begin{array}{l}2.87 \pm 1.79 \\
4.08 \pm 6.01 \\
6.72 \pm 7.53\end{array}$ & 2.426 & 0.097 \\
\hline $\begin{array}{l}\text { - Bilirubin } \\
\text { 2nd wk }\end{array}$ & $\begin{array}{l}\text { Erdosteine } \\
\text { NAC } \\
\text { Control }\end{array}$ & $\begin{array}{l}0.2-6.5 \\
0.2-27.3 \\
0.5-26.5\end{array}$ & $\begin{array}{l}2.87 \pm 1.95 \\
3.90 \pm 5.97 \\
6.61 \pm 7.49\end{array}$ & 2.340 & 0.106 \\
\hline $\begin{array}{l}\text { - Albumin } \\
\text { 1st wk }\end{array}$ & $\begin{array}{l}\text { Erdosteine } \\
\text { NAC } \\
\text { Control }\end{array}$ & $\begin{array}{l}1.2-3.8 \\
1.5-3.5 \\
1.5-3.5\end{array}$ & $\begin{array}{l}2.46 \pm 0.62 \\
2.50 \pm 0.59 \\
2.48 \pm 0.60\end{array}$ & 0.022 & 0.978 \\
\hline $\begin{array}{l}\text { - Albumin } \\
\text { 2nd wk }\end{array}$ & $\begin{array}{l}\text { Erdosteine } \\
\text { NAC } \\
\text { Control }\end{array}$ & $\begin{array}{l}1.2-4.1 \\
1.5-4.1 \\
1.5-3.5\end{array}$ & $\begin{array}{l}2.47 \pm 0.75 \\
2.61 \pm 0.70 \\
2.45 \pm 0.53\end{array}$ & 0.322 & 0.726 \\
\hline $\begin{array}{l}\text { - INR } \\
\text { 1st wk }\end{array}$ & $\begin{array}{l}\text { Erdosteine } \\
\text { NAC } \\
\text { Control }\end{array}$ & $\begin{array}{l}0.8-2.8 \\
1.05-2.3 \\
1.07-3.2\end{array}$ & $\begin{array}{l}1.64 \pm 0.61 \\
1.56 \pm 0.42 \\
1.87 \pm 0.63\end{array}$ & 1.621 & 0.207 \\
\hline $\begin{array}{l}\text { - INR } \\
\text { 2nd wk }\end{array}$ & $\begin{array}{l}\text { Erdosteine } \\
\text { NAC } \\
\text { Control }\end{array}$ & $\begin{array}{l}0.8-2.8 \\
1.01-2 \\
1.07-3.2\end{array}$ & $\begin{array}{l}1.65 \pm 0.60 \\
1.40 \pm 0.33 \\
1.88 \pm 0.65\end{array}$ & 3.942 & $0.025^{*}$ \\
\hline $\begin{array}{l}\text { Erdosteine } \\
\text { Erdosteine } \\
\text { NAC \& con }\end{array}$ & $\begin{array}{l}\& \text { NAC }(p) \\
\text { control }(p 2 \\
\text { trol }\end{array}$ & $\begin{array}{l}=0.155) \\
=0.177) \\
\left.=0.007^{*}\right)\end{array}$ & & & \\
\hline
\end{tabular}

Table (5): Effect of therapy on the grade of encephalopathy between studied groups.

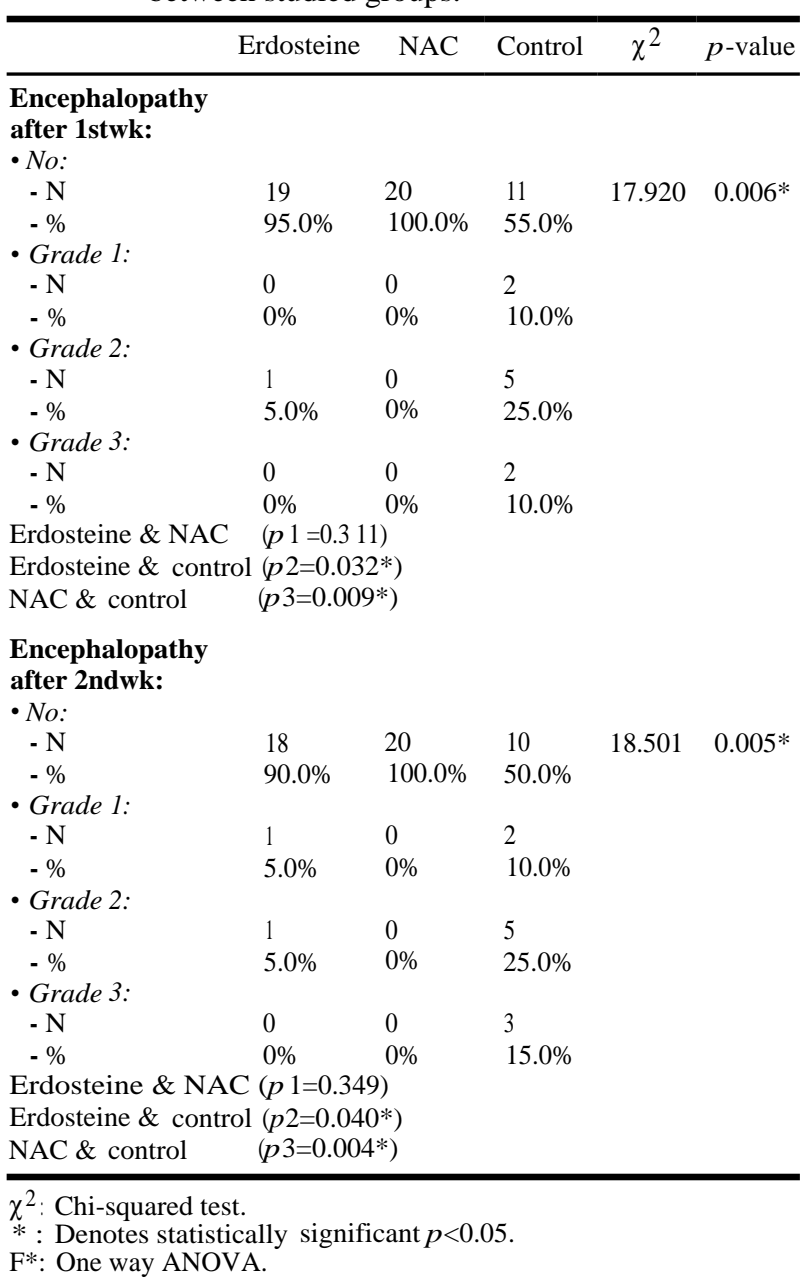

Table (6): Effect of therapy on Child-Pugh score between studied groups.

\begin{tabular}{lllll}
\hline \multicolumn{1}{c}{ Group } & & & \\
$\begin{array}{l}\text { Child- } \\
\text { Pugh score }\end{array}$ & Range & Mean \pm S.D & F-test & $p$-value \\
\hline lst $w k$ : & & & \\
$\quad$ Erdosteine & $6-13$ & $9.85 \pm 2.11$ & 3.144 & 0.051 \\
$\quad$ NAC & $7-12$ & $9.35 \pm 1.46$ & & \\
Control & $7-15$ & $10.90 \pm 2.31$ & & \\
2nd $w k$ : & & & \\
$\quad$ Erdosteine & $6-13$ & $9.85 \pm 2.11$ & 4.499 & \\
$\quad$ NAC & $7-12$ & $9.15 \pm 1.31$ & & \\
Control & $7-15$ & $11.00 \pm 2.34$ & & \\
Erdosteine \& NAC & $(p 1=0.266)$ & & \\
Erdosteine \& control $(p 2=0.070)$ & & \\
NAC \& control & $(p 3=0.004 *)$ & & \\
\hline
\end{tabular}

* : Denotes statistically significant $p<0.0$.

$\mathrm{F}^{*}$ : One way ANOVA.

\section{Discussion}

HRS is a frequent complication in advanced cirrhosis and the prevalence of HRS parallels the progression of liver disease in patients with cirrhosis [17]. Approximately $20 \%$ of cirrhotic patients with diuretic-resistant ascites potentially develop HRS, [18] the incidence of HRS in patients with cirrhosis at one year is $18 \%$, rising to $39 \%$ at five years after initial diagnosis [19]. Liver transplantation is the cornerstone for its management [1] Several meta-analyses that evaluated vasoconstrictor therapies for HRS did not show any significant reduction in mortality without liver transplantation [2-8]. Search for new therapies for HRS is needed.

NAC is used as an antidote for acetaminophen overdose, it is also used to treat Non-Acetaminophen-Induced Acute Liver Failure (NAIALF) and severe alcoholic hepatitis. When used to treat severe alcoholic hepatitis, i.v. acetylcysteine serves as an antioxidant and glutathione source. Improvement in patients with hepatorenal syndrome was also noted [9]. Erdosteine belongs to the class of mucolytics which is used for the treatment of wet cough and Chronic Obstructive Pulmonary Disease (COPD) [20] . Erdosteine may have multiple mealanisms to protect against hepatotoxicity and nephrotoxicity [21-23].

The aim of the present study was to determine the efficacy and safety of NAC versus Erdosteine in patients with HRS.

In our study, creatinine level was significantly lower after the second week of NAC therapy than baseline level $(p=0.006)$. Also there was significantly higher GFR after the first and the second weeks of NAC therapy than baseline level ( $p=$ 
$0.038,0.001$ respectively) and significant higher GFR after the second week than after the first week of the NAC therapy $(p=0.015)$. This was similar to a study that evaluated the effects of NAC on 12 patients with HRS; nine of 12 patients had alcoholic cirrhosis and/or alcoholic hepatitis. Treatment was well tolerated and renal function improved [24] This was also in agreement with Baker et al., [25] who prospectively treated 80 patients with stable renal dysfunction undergoing cardiac catheterization with intravenous NAC; serum creatinine was significantly reduced in the NAC group compared to the control group.

Also, a study of 83 patients with chronic renal insufficiency evaluated the use of NAC as a protective agent against contrast induced renal impairment; in this study, 10 patients had a rise in serum creatinine; of these, 9 were in the placebo group [26]. On the other hand, this was in contradiction with Webb et al., [27] who performed a prospective, randomized, placebo controlled trial $(n=487)$ evaluating a single bolus dose of intravenous NAC (500mg over 15 minutes) immediately before cardiac catheterization; a decline in creatinine clearance of $>5 \mathrm{ml} / \mathrm{min}$, was not significantly different between the study groups.

In our study, comparing all the 3 groups at the same time, creatinine and GFR showed non-significant difference between NAC, Erdosteine and control groups after the first or second weeks of therapy. On contrast, a study investigated the effects of Erdosteine on cyclosporin-A induced nephrotoxicity and concluded its protective action [21] .

Another study compared the effects of $\mathrm{N}$-acetyl cysteine and Erdosteine in rats with renal injury caused by paracetamol intoxication. In the groups treated with erdosteine or $\mathrm{N}$-acetyl cysteine after paracetamol, biochemical analyses, radionuclide imaging, and histopathological parameters showed significantly less evidence of renal toxicity than that observed in the group receiving paracetamol alone. Less renal toxicity was detected in rats receiving $\mathrm{N}$-acetyl cysteine than in those receiving Erdosteine [28]. Reno protective effect of Erdosteine in rats against gentamicin nephrotoxicity supported a protective role of Erdosteine in nephrotoxicity associated with gentamicin (GM) treatment [22] .

In HRS, there is no real cell damage it is only functional impairment. $\mathrm{N}$-acetyl cysteine and Erdosteine act as antioxidants, and in the current study we detected a significant improvement of the grade of encephalopathy and decrease in the amount of ascites in group II patients treated with
NAC in addition to the conventional treatment. Also, prothrombin activity significantly improved after 2 weeks of NAC therapy compared to baseline value $(p=0.01)$ and compared to the control group $(p=0.007)$. Moreover, Child-Pugh score significantly improved in NAC group compared to control group after 2 weeks of therapy $(p=0.004)$. By improving liver condition, HRS might show some improvement.

This was in agreement with Keays et al., [29] who suggested beneficial effects of NAC when given to patients with fulminant hepatic failure secondary to paracetamol toxicity as $48 \%$ of those receiving NAC survived compared to $20 \%$ of controls. This was in contradiction with Whilst Prescott et al., [30] who showed no benefit when NAC was commenced after 10 hours of paracetamol toxicity (with linear increase in those sustaining severe liver damage with increasing time from ingestion to NAC therapy).

In the first and second weeks, the grade of encephalopathy was significantly lower in Erdosteine group $(p=0.032,0.040)$ and in NAC group $(p=0.009,0.004)$ than control group. This was in agreement with a previous study demonstrated that, in the prevention of liver damage induced by acetaminophen intoxication, early treatment with a single dose of Erdosteine was beneficial instead of NAC administration and may be considered as an alternative treatment in liver damage [31]. In a study by Kuvandik et al., (2008) [23] in rats with acetaminophen-induced liver damage, they used 150 and $300 \mathrm{mg} / \mathrm{kg}$ of Erdosteine and demonstrated that the liver status improved to a similar degree with both doses.

Our study was a pilot study that investigated the effects of Erdosteine versus NAC on human patients with HRS. As these drugs had a high safety profile, we recommend further studies using higher doses of the drugs for longer periods and enrollment of larger number of patients to optimize treatment of HRS.

\section{References}

1- BELLOT P., FRANCÉS R. and SUCH J.: Pathological bacterial translocation in cirrhosis: Pathophysiology, diagnosis and clinical implications. Liver Int., 33: 31-9, 2013.

2- FABRIZI F., DIXIT V., MESSA P., et al.: Terlipressin for hepatorenal syndrome: A meta-analysis of randomized trials. Int. J. Artif. Organs., 32: 133-40, 2009.

3- FACCIORUSSO A., CHANDAR A.K., MURAD M.H., et al.: Comparative efficacy of pharmacological strategies 
for management of type 1 hepatorenal syndrome: A systematic review and network meta-analysis. Lancet. Gastroenterol. Hepatol., 2: 94-102, 2017.

4- GIFFORD F.J., MORLING J.R. and FALLOWFIELD J.A.: Systematic review with meta-analysis: Vasoactive drugs for the treatment of hepatorenal syndrome type 1 . Aliment. Pharmacol. Ther., 45: 593-603, 2017.

5- GLUUD L.L., CHRISTENSEN K., CHRISTENSEN E. and KRAG A.: Systematic review of randomized trials on vasoconstrictor drugs for hepatorenal syndrome. Hepatology, 51: 576-84, 2010.

6- GLUUD L.L., CHRISTENSEN K., CHRISTENSEN E. and KRAG A.: Terlipressin for hepatorenal syndrome. Cochrane. Database. Syst. Rev., 12 (9), 2012.

7- MATTOS A.Z., MATTOS A.A. and RIBEIRO R.A.: Terlipressin versus noradrenaline in the treatment of hepatorenal syndrome: Systematic review with metaanalysis and full economic evaluation. Eur. J. Gastroenterol. Hepatol., 28: 345-51, 2016.

8- SAGI S.V., MITTAL S., KASTURI K.S., et al.: Terlipressin therapy for reversal of type 1 hepatorenal syndrome: a meta-analysis of randomized controlled trials. J. Gastroenterol. Hepatol., 25: 880-5, 2010.

9- BASS S. and ZOOK N.: Intravenous acetylcysteine for indications other than acetaminophen overdose. Am. J. Health. Syst. Pharm., 70 (17): 1, 496501, 2013.

10- DAL NEGRO R.W., VISCONTI M., MICHELETTO C. and TOGNELLA S.: Changes in blood ROS, e-NO, and some pro-inflammatory mediators in bronchial secretions following erdosteine or placebo: A controlled study in current smokers with mild COPD. Pulm. Pharmacol. Ther., 21 (2): 304-8, 2008.

11- KOC A.1, DURU M., CIRALIK H., AKCAN R. and SOGUT S.: Protective agent, erdosteine, against cisplatininduced hepatic oxidant injury in rats. Mol. Cell. Biochem. Oct., 278 (1-2): 79-84, 2005.

12- SARITAS A., KANDIS H., BALTACI D., et al.: N-Acetyl cysteine and erdosteine treatment in acetaminopheninduced liver damage. Toxicol. Ind. Health. Aug., 30 (7): 670-8, 2014.

13- YESILDAG A.1, OZDEN A., YILMAZ H.R., et al.: Erdosteine modulates radiocontrast-induced hepatotoxicity in rat. Cell. Biochem. Funct. Apr., 27 (3): 142-7, 2009.

14- LEE J.Y., KIM H.S., PARK C.S. and KIM M.C.: Erdosteine in renal ischemia-reperfusion injury: An experimental study in pigs. J. Vet. Med. Sci. Jan., 72 (1): 1, 27-30, 2010.

15- PUGH R.N., MURRAY-LYON I.M., DAWSON J.L., et al.: Transection of the oesophagus for bleeding oesophageal varices. Br. J. Surg. 60: 646-9, 1973.

16- SALERNO F., GERBES A., GINÈS P., WONG F. and ARROYO V.: Diagnosis, prevention and treatment of hepatorenal syndrome in cirrhosis. Gut., 56: 1310-8, 2007.

17- WADEI H.M. and GONWA T.A.: Hepatorenal syndrome in the intensive care unit. J. Intensive Care Med., 28: 7992, 2013.

18- FEDE G., D'AMICO G., ARVANITI V., TSOCHATZIS E., GERMANI G., et al.: Renal failure and cirrhosis: A systematic review of mortality and prognosis. J. Hepatol., 56: 810-8, 2012.

19- GINÈS P., GUEVARA M., ARROYO V. and RODÉS J.: Hepatorenal syndrome. Lancet, 362: 1819-27, 2003.

20- MAURIZIO MORETTI POSTED: Pharmacology and Clinical Efficacy of Erdosteine in Chronic Obstructive Pulmonary Disease. Expert. Rev. Resp. Med., 1 (3): $307-$ 16, 2007.

21- TUTANC M., ARICA V., YILMAZ N., NACAR A., ZARARSIZ I., BASARSLAN F., et al.: Effects oferdosteine on cyclosporin-A induced nephrotoxicity. Hum. Exp. Toxicol. Hum. Exp. Toxicol. Jun., 31 (6): 565-73, 2012.

22- CABUK M., GUREL A., SEN F. and DEMIRCAN N.: Renoprotective effect of erdosteine in rats against gentamicin nephrotoxicity: A comparison of $99 \mathrm{mTc}$-DMSA uptake with biochemical studies. Mol. Cell. Biochem., 308 (1-2): 35-42, 2008.

23- KUVANDIK G., DURU M., NACAR A., et al.: Effects of erdosteine on acetaminophen-induced hepatotoxicity in rats. Toxicologic Pathology, 36: 714-9, 2008.

24- HOLT S., GOODIER D., MARLEY R., et al.: Improvement in hepa torenal syndrome with $\mathrm{N}$-acetylcysteine. Lancet., 353: 294-5, 1999.

25- BAKER C.S., WRAGG A., KUMAR S., et al.: A rapid protocol for the prevention of contrast-induced renal dysfunction: The RAPPID study. J. Am. Coll. Cardiol., 41: 2114-8, 2003.

26- TEPEL M., VAN DER GET M., SCHWARZFELD C., LAUFER U., LIERMANN D. and ZIDEK W.: Prevention of radiographic contrast agent induced reductions in renal function by acetylcysteine. N. Engl. J. Med., 343: 1804, 2000.

27- WEBB J.G., PATE G.E., HUMPHRIES K.H., et al.: A randomized controlled trial of intravenous Nacetylcysteine for the prevention of contrast-induced nephropathy after cardiac catheterization: Lack of effect. Am. Heart. J., 148: 422-9, 2004.

28- KANDIŞ H., ERKAN M.E., YILDIRIM U., GÜNEŞ H., ERBAŞ M., YILDIRIM H.A., GEZER S. and KARA I.H.: Comparison of the effects of $\mathrm{N}$-acetyl cysteine and erdosteine in rats with renal injury caused by paracetamol intoxication. Hum. Exp. Toxicol., 30 (9): 1, 350-8, 2011.

29- KEAYS R., HARRISON P.M., WENDON J.A., et al.: Intravenous acetylcysteine in paracetamol induced fulminant hepatic failure: A prospective controlled trial. $\mathrm{Br}$. Med. J., 303: 1026-9, 1991.

30- PRESCOTT L.F., ILLINGWORTH R.N., CRITCHLEY J.A.J.H., STEWART M.J., ADAM R.D. and PROUDFOOT A.T.: Intravenous Nacetylcysteine: The treatment of choice for paracetamol poisoning. Br. Med. J., 2: 1097 $100,1979$.

31- AYHAN S., HAYATI K., DAVUT B., UMRAN Y., HALIL $\mathrm{K}$., et al.: N-Acetyl cysteine and erdosteine treatment in acetaminophen-induced liver damage. Toxicol. Ind. Health Aug., 30 (7): 670-8, 2014. 


\section{تأثير عقار الأردوستين مقابل عقار ف-أستيل سستيين

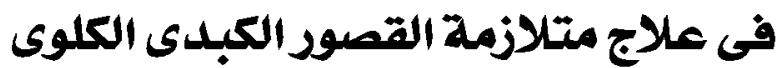

متلازمة القصور الكبدى الكلوى هو شكل فريد من قصود كلوى حاد يظهر فى المرضى الذين يعانون من الفثل الكبدى الهاد أو أمراض

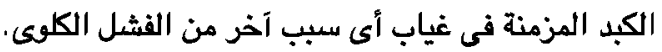

يعمل ن-أستيل سستيين كمضاد اللسموم، سواء بصورة مباشرة كبديل الجلوتاثيون وغير مباشرة تمهيداً للجلوتاثيون وعندما يستخدم بالويد لعلاج ألتهاب الكبد الكحولى الهاد، يقدم أستيل كمصدر للاكسيدة والجلوتاثيون.

وقد لوحظ التعسن فى المرضى الذن يعانون من متلازمة القصود الكبدى الكلوى أيضاً مع إستخدامه.

ينتمى الأردوستين إلى فئة من مذييات السعال والذى يستخدم لعلاج السعال الرطب ومرض الأنسداد الرئوى المزمن ويستخدم أيضاً كمادة

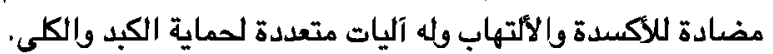
تهذف الدراسة إلى مقارنة تأثير عقار الأردوستين مقابل عقار ن-أستيل سستيين فى علاج متلازمة القصود الكبدى الكلوى.

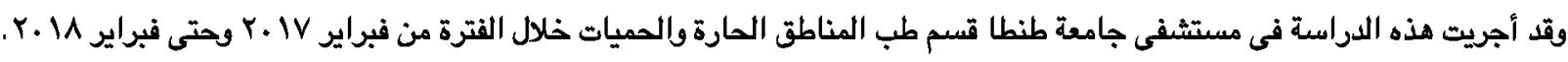

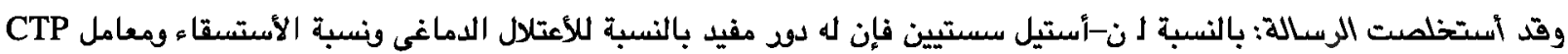

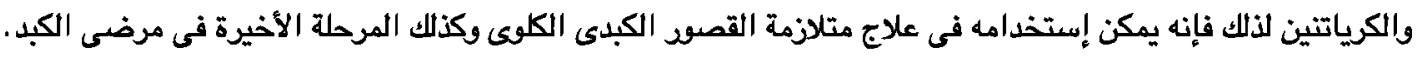
بالنسبة للأردوستين فأنه لا يعتبر أقل شئاًاً من ن-أستيل سسشيين فى علاج متالازمة القصور الكبدى الكوىى لملاحظة التحسن فى الأعتلال الدماغى عند إستخدامه. 